\section{DISSENSIONS IN THE UNIVERSITY OF LONDON.}

\section{To the Editor of The LANCET.}

Sir, - In consequence of two professors, supposed, on account of their conduct, to have been Professors Davis and Conolly, having gone to the warden and alarmed him by stating, what is known by all my friends to be untrue, that I intended to excite a disturlsance at the Medical Society of the University,-the warden, without saying any-thing to me, or to any of my friends, ordered the porter to prevent my entrance into the University. The pupils, therefore, like honest men, gave wo that hearing, which the council and warden had denied me, and afterwards sent me the following documents, of which $1 \mathrm{am}$ indeed proud, because they show the rising spirit of the young men of the present day. You will oblige me by publishing them with my answer.

Alex. Thouson.

"University of London, Oct. 14.

"Dear Sir, - We hare great pleasure in enclosing the resolutions agreed upon at the meetin, yesterday, with only two dissentient roices, and remain,

" Dear Sir, yours very truly, "N. Wisdell, Chairman.

" T. Howirt, secretary.

"At a meeting of the medical students of the Iondon Iniversity, beld in their com. mon room, on Wednesday, the 13th of Oc. tuber, 1830, it was resolved, that

"1. This moeting views with anxious concem the unmerited displeasure of the council, lately mantested toward their fellow surlent Dr. Alexander Thomson.

" 2 . Dr. $A$. I'lomson having fully laid before the students of the Unicersity, every particular of lis late conduct in connexion with that institution, and submitted to their perusal aubentic docaments in support of his statements, this meeting beigs respectfully to intimate to the council its unqualitiel approbation of the motives 1)r. Thomson acted unon in the transactions alluded to.

"3. The students are fully aware of the deference they awe to the ordinances of the cruncil, but cannot view, without apprebension, the summary measure which has been fiut in force in the case of Dr. A. Thomson, viz., hos extrardinary expulsion from the l nivereity. The conceive it to be a public in-titution, estabinhed on a system of eulutred and scienulic usefuness to society;

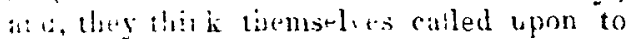
enter their tirm prote-t anainst the dismissal of a pupia 1 um its class-rooms, "lationt bis having rinluted ans known law, any hearing oi esidence, or eren an oflicial notice of his dismissal. 'They are convinced that a proceeding so arbitrary, irregular, and unjust, is incompatible with the best interests of the University, and subversive of the liberal principles, to which it owes its foundation and support.

"The following students have appended their names to the above resolutions :-

65, N. Eisdell, Chairman.

1. W. Calvert

3. B. D. Goodwin 50. D. W. Nash

3. E. Meryon 51. W. Rayner

4.IV.C.Copperthwaiteร2. J. Storar

5. C. R. Bree 53. J. Wakefield

6. J. Boosey 54. Jos. Thompson

7. A. Little 55. R. G. Shnte

8. J.Skitt 56. W. Cluley

9. W. P. Jorden $\quad 57$. J. Douglas

10. W. Bayes 58. W. Bennett

11. C. Harland 59. M. Brown

12. W. Erans 60. W. G. Driver

13. W. M'Kie 61. W. Johnson

14. IV. Thisselion 62. J. N. Hudlestone

15. W. Mumford 63. G. Hume

16. W. Player 64. 'T. Pidwell

17. H. Bird 66. R. Garner

18. C. G. De Morgan 67. W. Adamthwaite

19. H. Devonshire 68. E. Parslow

20. J. Johnson 69. J. Hull

21. J. Herris 70. J. Dyer

22. T. Woolwridge 71. T. Cutler

23. T. Johnson 72. C. G. Ford

24. R. Dudley 73. J. P. Litchfield

25. T. G. Wright 74. J. P. Wallis

26. R. W. Semple 75. A. M. à Beckett

27. J. H.Worthingtou76. J. I.Iassey

28. M. Cowan 77. J. Kayner

29. H. W. Lloyd 78. J. Merriman

30. S. Chadrick 79. T. Chandler

31. P.H.Edge 80. J.Thomson

39. J. R. Noble 81. A. Sisson

33. S. Dullen 82. C. Roberts

3\%. J.R. Lewis 83. W. Reily

35. Hunbury Smith 84. Henry Thomas

36. J.T. Owen 85. R. Wakefield

37. R. Jowett 86. W. Tomkyns

ว̈3. W. G.S. Clack 87. W. Wlsworth

39. G L. Cooper 88. B. Johnson

40. R. Smith Orwen 89. R. Stevens

41. P. Walsh 90. S. N'Morris

49. T. D. Goodridge 91. E. Norton

43. F. Spry 92. J. C. Leadbeatter

1.1. Chas. Thompson 93. J.. W. Holland

45. IV. James 94. John Chisholm

46. W. Jay 9. Millward Pogson

17. J. Weston 96. T. Howitt, Secre-

43. 'T. Davie

tary."

Many of my fellow pupils have called upon me, and informed me, that double the number of names would have been appeuded, had a conmunication not been made from the office, stating that I was not a matriculated pupil. As soon as I heard of this, [ sent the following letter to the warden:- 
"Sir,-Having received a very gratifying comminication from ninet $y$-six of my fellow students, approving of my conduct in regard to Professor Pattison, and haviug been inform. ed by many others of them, who have not appended their signatures to this document, that they have been restrained, by a commanication from the office affirming that I am not amatriculated student, from appending their names to this document, the whole tenour of which they otherwise approve; I beg to express to you my surprise at such information, and to inform you, that the moment I heard of it, I went to the office and tendered my money for a library ticket, which was refused. I assure you, that I have been attending the University under the belief that I was a regularly matriculated student; for, when I feed Dr. Davis for his lectures, he infurmed me publicly, in the presence of his class, that his share of the money at least would be remitted to me from the office.* This money I have never received, although I have more than once applied to Dr. Davis for it. I concluded, therefore, that this money was left for me at the office, where I wished it to remain, as my matriculation fee. Under this belief I attended many of the lectures last year. Again, Sir, I wish to ask of you whether, as a gentleman per. mitted by the council, through courtesy, to attend lectures in their institution, they give you authority to prohibit my entrance without sending ine any written document, and through the mouth of the porter? A gain, Sir, I wish to know whether you can expel me from, or prevent me entering, the medical society, of which I was the founder, as well as fromer of its laws, and an still an honorary member, having paid all $m y$ fees. If 1 , an oid pupil by your acknowledrment, am excluded in this manner, of whit use is it to me to have paid all my fees to that society? An answer to these queries will oblige

"Your obedient servant, (Signed) "Alex. 'ThOMSON. "October 15th, 1830."

To those Pupils of the University of London, who have signed the Protest to the Cruncil in favour of Dr. Alex. Thomson.

"Gentlemen,-Allow me to return you mr thanks for the lind interest you have taken an my welfire; I wish you had rather lad notal courage enough to have insisted

* There is an axreement among the professurs, that the will receive no money from their col1' 1-1tes' suls. Bul the councll do not saretion it 1 , d blertent, and, therefore, the sons are oblized 1. purciane a library ticket eacin year, as no unt lo prermited to luy a library tichet who does not Intw d to riter to a course of lectures, to pay that fart of the fee which goes to the Unversity chest. upon your own rights, and then you wotild not have been insulted by the council, ${ }^{*}$ who after reading your testimonial, sent me a letter, of which the following is a copy :-

\section{Copy of tice Warden's letter to Dr. Thomson.}

"University of London, Oct. 15, 1830 , " Sir,-I have laid your letter of this date before the council, and I am directed to transmit to you the following resolutions of the council passed this day :-

“"That Dr. Alexander Thomson be not permitted in future to come within the precincts of the University, and that the warden do give the necessary orders for carrying this resolution into effect.

" ' That a copy of the preceding resolution be transmitted to Dr. Alexander 'Thomson.' " 1 am, Sir,

"Your very obedient servant, "Leonard Horner, Warden. "Dr. Alex. Thomson."

"Moreover, Gentlemen, they have come to a resolution to take no notice whatever of your protest, and on no account to acknowledge the students as a body possessing any rights, but such as they in courtesy may choose to grant. If you are idiots and cowards enough to submit to this, you deserve all the inflictions which that body can impose upon you, and will, in the language of your haughty professor of midwifery, be "crushed." T have done my duty in giving you the opportunity of asserting your independence: I deeply regret the existence in so large a body of young and strong men, of the pusillanimity and weakness of intellect which has made you neglect it.

"Your fellow student,

"October 18th, 1830."

$$
\text { "Arex. "Thomson. }
$$

MEDICAL ELECTIONS.

\section{To the Editor of THE LAvcr.T.}

$S_{I R},-I$ and many of my brother pupils should esteem it a particular favon:, if you would insert in your Lancer of next Saturday, the following passage from Mr. Dermott's introd:actory lecture. You wull, I am sure, be pleased to learn, that the entire address consisted of an able condensation of those aroments which you have $: 0$ repeat-

* It is better, however, to observe to von, that not more than six nember of courcil hite on this oc. casion, as $I$ am crethbly infomited by two of the professors. Dr. Wibleck and Hr. Stu.ch werc, I am also told, of the number. 